\title{
Solar and Biomass Gasification: A Solution to Boost Shrimp Farming Businesses
}

\author{
Maesha Gusti Rianta \\ Directorate of Industry, Tourism, and Creative Economy \\ Ministry of National Development Planning \\ Jakarta, Indonesia \\ maeshagustirianta@gmail.com
}

\author{
Dwiputra Ahmad Ramdani \\ Center of Policy Analysis \\ Ministry of National Development Planning \\ Jakarta, Indonesia \\ dwiputra.ramdani@gmail.com
}

\begin{abstract}
Electricity is a primary need in everyday life which can also boost regional economic growth. Tulang Bawang regency, located in Lampung Province, is one of the region in Indonesia in which its economy is heavily depended on electricity. Electricity is utilized to support operational activities of their shrimp farming businesses.
\end{abstract}

This paper aims to assess the feasibility of providing electricity using a combination of biomass gasification and solar energy to support shrimp farming activities. This study covers three electricity generation scenarios to supply 540 MWh electricity annually: 1. Using diesel generator as how the condition right now is, 2. Using solar panel and diesel generator, and 3. Using solar panel and rice husk gasification. Energy simulations are performed using Homer software, while financial simulations are conducted in Excel. The findings of those scenarios revealed that using an integration of solar panel and rice husk gasification (scenario 3) can reduce the LCOE by $78 \%$, from IDR 3750/kWh in the first scenario into IDR 820/kWh in the third scenario.

In order not to encumber the shrimp farmers, this study also assess two payment scenarios: (a) pay as you go electricity billing, which is lower than national electricity tariff (TDL) and (b) paid after the shrimp harvest season in which the revenue sharing between farmers and investors is $89 \%$ and $11 \%$ respectively. The latter is more profitable for investors, while the former brings a more stable profit for investors.

Keywords-renewable energy; solar panel; financial model; biomass; energy modeling

\section{INTRODUCTION}

Nowadays, electricity is one of the primary needs for human life. The use of electricity is spanning from simple activities such as charging smartphone and watching TVs, to complicated activities such as powering engines in manufacturing industries. As technology is growing rapidly, the need of electricity is also increasing significantly (IEA, 2015). This phenomenon is not only occurring in developed countries, but also in developing countries including Indonesia. Electricity becomes one parameter that determines how a country develops.
Bumi Dipasena is located in Tulang Bawang Regency, Lampung Province. Back then, in 1998, Bumi Dipasena was widely renowned as the biggest shrimp producer in Asia. Shrimp farming requires stable electricity to power pumps, aerator and other equipment to maintain the growth of the shrimps. For many years, electricity required for shrimp farming in Bumi Dipasena was supplied by two companies called Dipasena Citra Darmaja and Aruna Wijaya Sakti. However, since 2007, there was no longer electricity supplied to Bumi Dipasena. As a result, farming activities totally stopped for a while. As an effort of local farmers to reactivate the farming activities, they then started using diesel generator. However, due to the high cost required to produce electricity from diesel generator, it was only a few farms that could be productive again. The remaining farms just left idle until now.

Located near the equator line, the sun irradiance of Bumi Dipasena is high enough reaching $4.83 \mathrm{kWh} / \mathrm{m}^{2} /$ day. Thus, the utilization of solar energy through solar cells needs to be taken into consideration. However, due to its intermittency, solar cells must be prevented to be the sole electricity source if the stable output of electricity is expected. Otherwise, large area of land for solar cells installment and many batteries are required which cause the cost to be pretty high, even higher than the cost required for diesel generator. Thus, other renewable sources need to be investigated to back-up the solar cells. Fortunately, Bumi Dipasena is near Rawajitu Selatan which is an agricultural area. In a year, Rawajitu Selatan can produce averagely 9000 tons of rice husk and 45000 tons of rice straws. Through biomass gasification process, rice straws and rice husk can be processed to generate electricity and become the back-up source of solar cells. Aiming to provide electricity for shrimp farming with affordable price, the feasibility of the hybrid of solar cells with biomass gasification was investigated in this study.

\section{ANALYTICAL FRAMEWORK}

The economic investigation of solar cells utilization was conducted by Subhan Nafis et al. (2015). In their case, the use of solar cells along with diesel generator, was intended to supply electricity for three areas that are located in Nias; Gunung Sitoli, Teluk Dalam and Pulau Tello. At the time the study was undertaken, most of electricity generation in those areas was from diesel power plant. Thus, a huge amount of diesel fuel was consumed every year, making the electricity 
production cost pretty high reaching IDR $2,763 / \mathrm{kWh}$. The study was aimed to find out if the utilization of solar cells was feasible to reduce the electricity production cost. For the sake of transmission system stabilization, the capacity of solar cells used was limited to only $20 \%$ of maximum demand of the areas at noon time. It means that in their study, diesel generator was still used but with less amount of fuel. Regarding to $20 \%$ of maximum demand, the values of solar cells capacity considered in their study were $1,960 \mathrm{kWp}, 720$ $\mathrm{kWp}$ and $58 \mathrm{kWp}$ for Gunung Sitoli, Teluk Dalam and Pulau Tello, respectively. Based on their calculation, the production costs of solar cells for Gunung Sitoli, Teluk Dalam and Pulau Tello were IDR 2,447/kWh, IDR 2,470/kWh and 2,450/kWh, respectively. With the use of solar cells in Gunung Sitoli, the amount of 2082 liters of diesel fuel could be saved in a day, whereas the reduction of daily diesel fuel consumption in Teluk Dalam and Pulau Tello were 811 liters and 75 liters, respectively. With the reduction of diesel fuel consumption, the total annual cost that could be reduced was approximately IDR 7.63 billion (Nafis et al., 2015).

The utilization of renewable sources for shrimp farming was investigated by Dharma Arinda. The shrimp farm taken as his object of study was located in Muara Gembong, Bekasi. In that location, electricity for shrimp farming was generated only by diesel generator. Thus, the study analyzed how much cost could be saved if electricity demand was supplied by the hybrid of wind turbine, solar cells and diesel generator. The annual electricity consumption was $18,360 \mathrm{kWh}$. If the electricity was just generated by diesel generator, approximately 24,480 liters of diesel fuel was consumed in a year. For the hybrid system, the capacity of wind turbine. solar cells and diesel generator were $1.5 \mathrm{~kW}, 0.5 \mathrm{kWp}$ and $3.5 \mathrm{kVA}$, respectively. The study showed that the use of hybrid system of wind turbine, solar cells and diesel generator could reduce the cost of diesel fuel as much as IDR 109,710,000 per year. Furthermore, the use of hybrid system could also increase the revenue gained by shrimp farmers from IDR 152,900,000 if only using diesel generator to IDR $247,710,000$ if using hybrid system (Dangkua, 2011).

Beside solar energy, as an agricultural country, Indonesia has huge potential of biomass coming from agricultural waste (IEA, 2015). According to Syukri M. Nur, there are several aspects that need to be considered when planning the utilization of biomass for electricity generation (Nur, 2013). The first aspect is the availability of biomass sources. The availability is not just about quantity but also quality and sustainability. Biomass needs to have adequate energy content and least amount of water content. Moreover, the source of biomass should be near power plants using that biomass. The second aspect is the selection of energy conversion methods. The conversion process of biomass energy can be conducted by directly combusting the biomass (combustion process), converting biomass into gas (gasification) and pyrolysis process. Different types of conversion processes involve different types of technology. The third aspect is the maturity of technology. Generally, technology for combustion process is more mature than gasification process and pyrolysis. Gasification process is known as new technology so its deployment is just begun. The forth aspect is financial aspect that can be represented by levelized cost of electricity (LCOE). LCOE is simply the amount of cost spent for building and operation to generate $1 \mathrm{kWh}$ electricity over an assumed financial life and duty cycle (EIA, 2017).

Although still unpopular, gasification process is more appropriate to maximize the utilization of biomass energy rather than direct combustion. For gasification process, the common agricultural wastes used are rice husk and rice straw which are the side products of paddy farming. The amount of rice husk produced from the production of $1 \mathrm{~kg}$ rice is around 0.2 to $0.3 \mathrm{~kg}$, or around $20-30 \%$ from total rice produced. The low heating value (LHV) of rice husk itself is around 3,300 $\mathrm{kcal} / \mathrm{kg}$ (Fatimah et al., 2014).

Adilla Mutia Fatimah et.al from Indonesian Institute for Energy Economics (IIEE) conducted a case study on biomass gasification in 2014. The purpose of the study was to give information about important factors determining the successfulness of biomass gasification project. In their study, the feasibility of biomass gasification was analyzed for a village in Bali called Munduk. Annually, rice husk that can be produced in Munduk is approximately 800 tons while the production of rice straw is 3,200 tons. Thus, in total, the annual agricultural waste from rice farming activities in Munduk is 4,000 tons. The rice husk and rice straw can be processed to generate electricity using biomass gasifier that is integrated with gas generator. Through gasification process, rice husk and rice straw is converted into gas which then the gas produced is flowing into generator. Gasifier used in their study was Trillion Gasifier Model 70 which theoretically could produce energy as much as $45 \mathrm{~kW}$. However, when the gasifier was connected to a gas generator, the maximum electricity generated reached only $24 \mathrm{~kW}$. The gasifier and gas generator was planned to operate 6 hours a day and consumed $180 \mathrm{~kg}$ of rice husk and rice straw. Thus, for monthly usage of gasifier, approximately $5,400 \mathrm{~kg}$ of rice husk and rice straw was used (Fatimah et al., 2014).

\section{METHODS}

There are four steps carried out to finish this feasibility study. The steps are explained below.

\section{A. Energy Demand Calculation}

In this step, annual electricity demand is calculated. Commonly, the duration of one cycle of shrimp farming is around 4 months. In other words, there are three cycles of shrimp farming in a year. Semi-intensive method is applied for the shrimp farming in this study. For a shrimp farm with area of 2,000 m2, semi-intensive method requires four aerators (1 HP each) and pumps. These equipment are not working for fully 24 hours and 365 days in a year, yet their operations are scheduled. Based on the schedule, the electricity demand profile for each shrimp farm in one cycle can be obtained. In this study, the number of shrimp farms that need to be supplied with electricity is 30 farms. The total annual electricity demand is $536,094 \mathrm{kWh}$. 


\section{B. Determining the Availability of Renewable Resources}

The availability of rice straw and rice husk located near the shrimp farms must be identified. Since the nearest agricultural area from Bumi Dipasena is in Rawajitu Selatan, the amount of rice husk and rice straw used as energy sources was obtained from the data of paddy production in Rawajitu Selatan. This data was acquired from the official website of the district of Tulang Bawang (tulangbawangkab.go.id). According to the website, the annual paddy production in Rawajitu Selatan is 47,737 ton. The amount of rice husk available was assumed to be $20 \%$ of total rice production in Rawajitu Selatan while the amount of rice straw was assumed to be the same with total rice produced.

The energy system was modelled by using a software called Homer. This software is equipped with solar resources data around the world. The users just simply put the specific location into the "solar resources input" box in the software to acquire daily radiation as shown in the figure below.

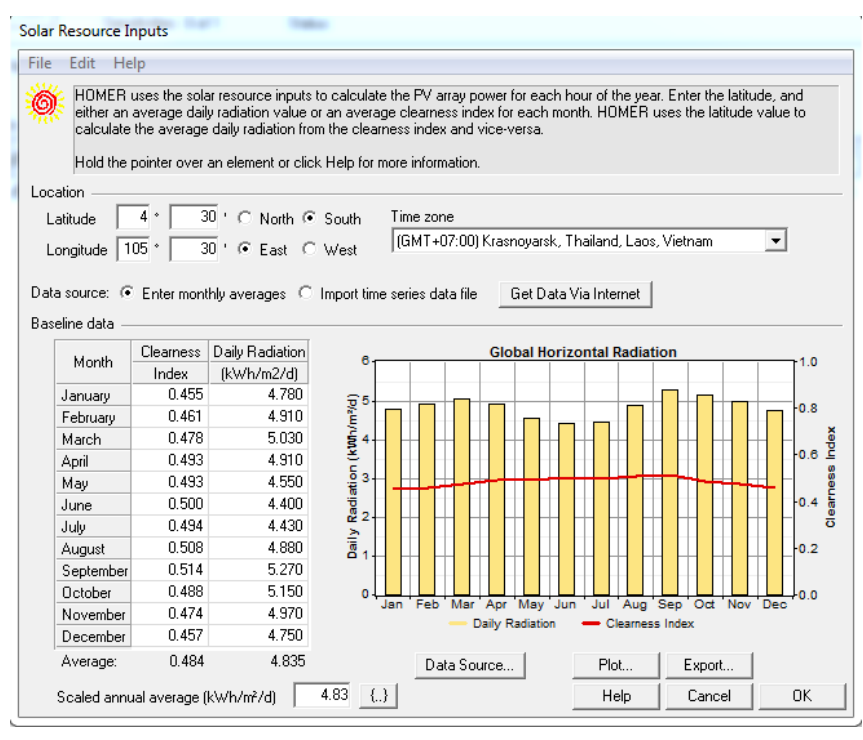

Fig. 1. Solar Resource Input box in the software

\section{Energy System Modelling in Homer Software}

Homer enables users to undertake a simulation and optimization process of energy systems with certain configuration. The simulation process determines whether certain energy system can adequately fulfill electricity load or not. Through the optimization process, many different configurations of the energy system were identified to obtain the one with the lowest life-cycle cost. Parameters required as the inputs to the software are annual electricity demand profile, the amount of available biomass resources, the price of biomass resources, the latitude and longitude of the location that is being investigated, all costs related with the biomass gasifier and solar cells such as capital, O\&M and replacement cost, the lifetime of biomass gasifier and solar cells, the derating factor of solar cells, the size of converter and so on.
Three scenarios were simulated in this study. In the first scenario, the electricity was only supplied by diesel generator. This scenario is the representation of the real situation occurred in shrimp farms in Bumi Dipasena. The second scenario was set to utilize solar cells as the main source of electricity generation and diesel generator as the backup plant. Lastly, in the third generation, all electricity demand was supplied by solar cells and biomass gasifier. Through energy system modelling in Homer, the configurations of energy system with the lowest life cycle cost for each scenario were obtained. Financial modelling is the next step where those three scenarios were compared among each other based on its LCOE.

\section{Financial Modelling}

The values of LCOE of each scenario were calculated manually by using Microsoft excel. The equation of LCOE used is shown below:

$$
\mathrm{LCOE}=\frac{\sum_{\mathrm{t}=1}^{\mathrm{n}} \frac{\mathrm{I}_{\mathrm{t}}+\mathrm{M}_{\mathrm{t}}+\mathrm{F}_{\mathrm{t}}}{(1+\mathrm{r})^{\mathrm{t}}}}{\sum_{\mathrm{t}=1}^{\mathrm{n}} \frac{\mathrm{E}_{\mathrm{t}}}{(1+\mathrm{r})^{\mathrm{t}}}}
$$

With:

$\mathrm{I}_{\mathrm{t}}=$ Capital investment in year $\mathrm{t}$

$\mathrm{M}_{\mathrm{t}}=$ Operation and maintenance expenditures in year $\mathrm{t}$

$\mathrm{F}_{\mathrm{t}}=$ Fuel expenditures in year $\mathrm{t}$

$\mathrm{E}_{\mathrm{t}}=$ Electricity generation in year $\mathrm{t}$

$\mathrm{r}=$ Discount rate

$\mathrm{n}=$ lifetime of the system

In this financial modelling, two payment schemes for customers were developed. The first one was revenue sharing. In this payment scheme, the shrimp farmers pay their electricity bill to the power producer by sharing a certain percentage of their revenue obtained from shrimp sales during shrimp harvest season. Thus, financial modelling was aimed to find what percentage of revenue sharing at which desired IRR could be attained by power producer company. The amount of shrimp farmers' revenue was calculated by multiplying total annual shrimps production with the price of shrimp. This calculation also took inflation rate into account. The percentage of revenue sharing is fixed. Thus, the amount of bill that shrimp farmers pay only depends on their revenue, no matter how much electricity they have used.

The second payment scheme is "pay as you go". This scheme is the common scheme of electricity payment. The shrimp farmers' electricity bill is determined only by how much they used the electricity from the power producer. Through the financial modelling, the electricity tariff that should be applied by power producer in order to achieve desired IRR can be done. It could be found out whether the electricity tariff is lower or higher than the national electricity tariff. 


\section{RESULT AND DISCUSSION}

The first scenario assessed was the current implemented scenario in Bumi Dipasena-Diesel generator. In order to fully supplied 30 farms, two diesel generators were needed, each with $75 \mathrm{~kW}$ in size (Table 1). The reason for using two generators instead of one $150 / 160 \mathrm{~kW}$ generator was because if one of the generator failed, the system would not be shutdown completely, there would be one generator that could back-up even though it would not be able to fully supply the farms with maximum intensity. This was important because electricity is essential to power the aerator, fans, etc., so that the oxygen level in each farm would be sufficient. The failure in providing electricity would result in significant reduction of the harvest. This diesel generator system requires a capital investment of approximately USD 136 thousand or IDR 1.8 billion with an operational cost of IDR 1.2 billion annually. This operational cost was mainly for diesel fuel consumption, consuming 240 thousand liters of fuel every year. Not only that this would put a burden in the cashflow, but it would also emit 630 tons $\mathrm{CO} 2$ each year. As for the LCOE of this system, calculated using $4 \%$ inflation rate and $10 \%$ discount rate, it amounted to IDR $3,750 / \mathrm{kWh}$.

TABLE I. ENERGY SySTEM MODELLING RESULTS

\begin{tabular}{|l|c|c|c|}
\hline & Full Diesel & Diesel + PV & $\begin{array}{c}\text { Gasification } \\
+\mathbf{P V}\end{array}$ \\
\hline Initial Capital (IDR) & 1.8 billion & 3.8 billion & 3.7 billion \\
\hline OPEX (IDR/yr) & 1.2 billion & 0.56 billion & 37.5 million \\
\hline Fuel (/yr) & 240,0001 & 130,0001 & $143 \mathrm{t}$ \\
\hline $\mathbf{C O}_{\mathbf{2}}$ Emissions (t/yr) & 630 & 420 & 230 \\
\hline $\mathbf{L C O E}($ IDR/kWh) & 3,750 & 2,865 & 810 \\
\hline
\end{tabular}

The second model used a solar photovoltaic system as its main source of electricity and was supported by a diesel generator as the back-up system, especially when the sun irradiation is scarce. The system would need $120 \mathrm{kWp}$ solar PV panels, a $70 \mathrm{~kW}$ diesel generator, 20 strings of $2.4 \mathrm{kWh}$ batteries, a $90-\mathrm{kW}$ inverter. The total initial capital for this system was approximately IDR 3.8 billion. Even though the initial capital was much larger than the previous system, but the operational cost was roughly cut by half, amounting to IDR 560 million annually. Similar to the previous system, this operational cost was mainly for fuel consumption, which consumed 130 thousand liters of fuel each year. It corresponded to approximately 420 ton of $\mathrm{CO} 2$ emission. Using the same assumption of inflation and discount rate, the LCOE for this second model was IDR $2,865 / \mathrm{kWh}$.

The last model simulated was a solar photovoltaic system that was backed-up by a biomass gasifier. This biomass gasifier used rice husks and straws for its fuel and was obtained by nearby rice paddy fields. Normally, the rice husks and straws can be obtained for free, but in this calculation, it was assumed the price of these agricultural wastes to be IDR $2,500 / \mathrm{kg}$, including the distribution cost from the mill/rice field into the biomass gasifier location.

Similar to the second model, this system also needed 120 $\mathrm{kWp}$ solar PV panels, 20 strings of $2.4 \mathrm{kWh}$ batteries, and a
90-kW inverter. But, instead of using diesel generator, this system used a 70-kW biomass gasifier. A total amount of IDR 3.7 billion was required for its initial capital cost. While its capital cost was quite huge comparing to the full-diesel system, its operational cost was very low, less than IDR 37.5 million each year. These corresponded to LCOE of IDR $810 / \mathrm{kWh}$. Not only that the LCOE of this system was the lowest, this system was also the cleanest compare to all models, emitted only 230 tons of $\mathrm{CO} 2$ each year. Considering this system prevented the burning of 143 tons of rice husks/straws in the field directly, the system net of $\mathrm{CO} 2$ emission might actually be decreasing. Based on these results, the third model utilizing solar PV panels and biomass gasifier is preferred.

An initial capital investment of IDR 3.7 billion might not be viable for most of shrimp farmers ( IDR 120 million per shrimp farm); then, this study examined two payment systems that would not put a burden into shrimp farmers' cash flow: revenue sharing and pay-as-you-go system.

Normally, 2.2 million fried shrimps are sown per one semi-intensive shrimp pond. Assuming the survival rate (SR) of these shrimps is $85 \%$ by the end of farming season, there will be 3.74 tons of shrimp ready to be harvested. It amounts to IDR $841.5 \mathrm{million} /$ pond/year, by assuming the shrimp price is IDR 75,000 and one year can have shrimp harvesting three times. Using the same assumption of inflation and discount rate, in order to have a $17 \%$ IRR (Fig. 2), it needs a revenue sharing of $11 \%$ for 5 years so that the investment can be seen as financially promising. The NPV of this scheme is approximately IDR 700 million. After 5-year contract, all renewable energy system will be transferred its ownership to the respective farmers or to the shrimp farmer cooperative of Bumi Dipasena.

As for the second scheme, in order to have a $17 \%$ IRR in 5 years, the electricity tariff needs to be IDR $2,443 / \mathrm{kWh}$. It is indeed higher than the national electricity tariff, but it is still lower than the current electricity cost using diesel generator (IDR 2,909/kWh). Not to mention that after 5 years, all the electric generation facilities will be owned by the respective farmers without any additional cost.

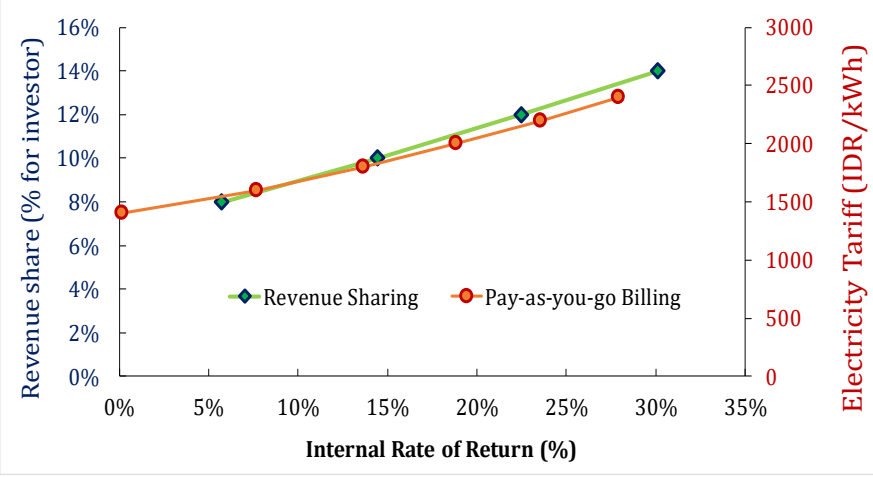

Fig. 2 Profitability comparison between revenue sharing and electricity tariff scenario 


\section{CONCLUSION}

Renewable energy system, especially combination between solar PV panels and biomass gasification can provide a more affordable electricity in Bumi Dipasena, compare to the current diesel generator system. LCOE of this hybrid power plant amounted to $78 \%$ lower than the diesel generator. Not only this hybrid system is cheap, but also this system contributes to a $\mathrm{CO} 2$ emission reduction with the utilization of rice husks and straws for biomass gasifier fuels, instead of directly burning these agricultural wastes. An initial capital of IDR 3.7 billion is needed to fully supply electricity of 30 shrimp farms by installing $120 \mathrm{kWp}$ solar PV panels, 20 strings of $2.4 \mathrm{kWh}$ batteries, a $90-\mathrm{kW}$ inverter, and a $70-\mathrm{kW}$ biomass gasifier.

Shrimp farmers can pay the electricity tariff in two schemes, the first one is revenue sharing of their shrimp sales with the ratio of $11 \%$ to the power producer. This payment is paid after they conducted the selling process, making this scheme will not put a burden to their financial. After five-year contract, the power plant is handed-out to them. Using this scheme, in five years, the power producer can obtain NPV of approximately IDR 700 million with an IRR of $17 \%$. The second scheme, pay-as-you-go, depends on the electricity consumption. This second scheme electricity tariff is still lower than current electricity cost using diesel generator, IDR 2443/kWh compare to IDR 2909/kWh. After five years, they can enjoy free electricity for their shrimp farms for another 15 years.

\section{REFERENCES}

Dangkua, D. A., 2011. Studi PLT Hibrid Angin-MatahariDiesel Untuk Penghematan Biaya Aerasi Tambak Udang di Muara Gembong Bekasi., s.l.: s.n.

EIA, 2017. Levelized Cost and Levelized Avoided Cost of New Generation Resources in the Annual Energy Outlook 2017, s.l.: s.n.

Fatimah, A. M., Ragina, F. S., Siahaan, N. \& Batih, H., 2014. Gasifikasi Biomassa: Studi Kasus Proyek di Desa Munduk, Buleleng, Bali, s.l.: s.n.

IEA, 2015. Indonesia 2015, Paris: International Energy Agency.

Nafis, S., Aman, M. \& Hadiyono, A., 2015. Analisis Keekonomian Penerapan Pembangkit Listrik Tenaga Surya Pada Sistem Ketenagalistrikan Nias, South Jakarta: s.n.

Nur, S. M., 2013. Strategi Perencanaan Pembangunan Pembangkit Listrik Berbasis Biomassa, Bogor: s.n. 